\title{
RHEUMATOID ARTHRITIS: DYE RETENTION STUDIES AND COMPARISON OF DYE AND RADIOACTIVELY LABELLED RED CELL METHODS FOR MEASURE- MENT OF BLOOD VOLUME*
}

\author{
BY

\begin{abstract}
ALLAN ST. JOHN DIXON, $\uparrow$ SAVITRI RAMCHARAN, AND MARION W. ROPES
From the Medical Clinic of the Massachusetts General Hospital and the Department of Medicine
\end{abstract} \\ Harvard Medical School, and the Massachusetts Department of Public Health, Boston, Massachusetts
}

(RECEIVED FOR PUBLICATION DECEMBER 14, 1954)

The congo red test for amyloidosis (Bennhold, 1923) measures the proportion of this dye which is retained in the plasma one hour after its intravenous injection. In our previous experience, 45 normal subjects retained 70 per cent. or more, and five patients with histologically proven amyloidosis retained 50 per cent. or less, usually much less, in this period. This is in accord with other reports (Bennhold, 1923; Friedman and Auerbach, 1935; Taran and Eckstein, 1942; Lipstein, 1938; Stemmerman and Auerbach, 1944; Harmon and Kernwein, 1942; Pearlman, 1940; Unger and others, 1948). However, in 114 out of 227 patients with rheumatoid arthritis, we found values between 50 and 70 per cent. These intermediate values point to a difference in the fate of intravenously injected dyes in patients with rheumatoid arthritis as compared with normals. Estimates of blood volume in this disease based upon dye methods may therefore not be accurate. The availability of the radioactive sodium chromate-51 $\mathrm{Cr}$ method (Sterling and Gray, 1950) enabled us to measure the blood volume of a series of such patients simultaneously by two methods, one of which did not depend on a dye. In addition, we have compared the one-hour retention of congo red with that of Evans' blue in another series of patients. These results and other observations relevant to these problems are herein reported.

\section{Methods}

Red cell masses were measured by the method of Sterling and Gray (1950) which utilizes the affinity of

* This is publication Number 179 of the Robert W. Lovett Memorial for the Study of Crippling Disease, Harvard Medical School. The expenses of the investigation were defrayed in part by a grant from the Commonwealth Fund.

by a grant from the Commonwealth Fund. Foundation, New York. sodium chromate for haemoglobin. About $35 \mathrm{ml}$. of the subject's blood was drawn, under sterile precautions, into a syringe containing $0.25 \mathrm{ml}$. 10 per cent. (weight for volume) heparin solution, and centrifuged (30 min., 2,700 r.p.m., $15 \mathrm{~cm}$. radius); the plasma was removed and the red cells gently mixed for one hour at room temperature with about $15 \mathrm{ml}$. normal saline containing approximately $1.5 \mathrm{mg}$. sodium chromate- ${ }^{51} \mathrm{Cr}$ with radioactivity of about 100 microcuries. The cells were then separated from the saline supernatant by centrifugation, and washed three times with fresh saline. After two such washings, the radioactivity of the supernatant became constant at approximately 1 per cent. The cells were then stored overnight at $4^{\circ} \mathrm{C}$. Before using they were resuspended in the original plasma (filtered through sterile gauze if any fibrin clot had formed overnight) and thoroughly mixed by continuously inverting the tube for $3 \mathrm{~min}$. A sample was removed for determination of radioactivity and haematocrit; the rest of the tagged blood being used for injection.

Plasma volumes were measured by a modification of the Evans' blue method of Gibson and Evans (1937) and by a modification of the congo red method of Rowntree, Brown, and Roth (1929). A $0 \cdot 1$ per cent. solution of Evans' blue was prepared in sterile ampoules. Two batches of dye were used; each was standardized separately according to the method of Gibson and Evelyn (1938) and checked against the other. Similarly, a 1 per cent. congo red solution was prepared and a single batch of ampoules were standardized by dilution in a 10 per cent. solution of serum in saline. Tagged cells or dye were injected, using syringes calibrated by weight. Blood was drawn from one anticubital vein for blank values of dye concentration or radioactivity, the needle left in situ, and the syringe containing dye or tagged cells substituted. Blood was taken from the opposite vein at $4,10,30$, and $60 \mathrm{~min}$. through a No. 19 needle with the tourniquet left on for about 15 seconds. Dye concentrations were measured against the pre-injection blank in a Junior Colman spectrophotometer, using serum or heparinized plasma. In one patient in whom both 
plasma and serum were used the results were identical. Optical density of the plasma at $625 \mu$ and $540 \mu$ (Evans' blue) and at 510 (congo red) were plotted on semilog paper against time. A few haemolysed samples, showing unexpectedly high absorbtion at $540 \mu$, were rejected. Almost all values lay on a straight line, showing that the loss of both dyes from the blood stream was exponential. This straight line was retropolated (as recommended by Gregersen and Schiro, 1938), and the optical density at zero time was used for calculating plasma volume (P.V.) according to the formula:

$$
\text { P.V. }=K \times \frac{\text { Amount of dye injected (mg.) }}{\text { Optical density at zero time }}
$$

where $K$ is the ratio of optical density to the concentration of the dye as determined by the slope of the calibration curve.

Plasma retentions of dye were calculated from the equation:

$$
\text { Retention }=\frac{\text { Optical density at zero time }}{\text { Optical density at } 60 \text { minutes }} \times 100 .
$$

using values for optical density derived from the graph. This is not quite the same as the standard method, which compares the observed 60-min. and 4-min. values. When measuring red cell mass (R.C.M.), the radioactivity of $1.0 \mathrm{ml}$. aliquots of tagged blood and of the 30- and 60-min. samples were compared in a scintillation counter (after correcting for background and for radioactivity of the respective plasmas) according to the formula:

\footnotetext{
R.C.M. $=$ Volume of tagged blood injected $\times$ the haematocrit of the tagged blood $\times$ counts per $\mathrm{ml}$. of tagged red cells $\div$ counts per ml. of red cells in sample.
}

The mean of the $30-$ and $60-\mathrm{min}$. results was taken.

Haematocrits were determined in duplicate in 2-ml. tubes with an internal diameter of $0.5 \mathrm{~cm}$. by centrifuging for $30 \mathrm{~min}$. at 2,700 r.p.m. with a $15-\mathrm{cm}$. radius, several different estimates being made on separate aspects of the tube. The mean of the 30- and 60-min. values was used, corrected by an arbitrary 97 per cent. to allow for trapped plasma. Total blood volume (Evans' blue or congo red methods) was calculated by dividing the plasma volume by the proportion of plasma in the corrected haematocrit. Total blood volume ${ }^{(51} \mathrm{Cr}$ method) was calculated by dividing the red cell mass by the proportion of red cells in the corrected haematocrit. "True" total blood volume (independent of the haematocrit) is the sum of the plasma volume (Evans' blue) and the red cell mass $\left.{ }^{(51} \mathrm{Cr}\right)$. Surface area was computed according to the tables of Dubois (1927), as modified by Boothby and Sandiford (1929). Height was measured erect if the subject could stand straight, or in bed using a flexible tape measure where deformities were present. Sedimentation rates were measured by the method of Rourke and Ernstene (1930) and were corrected for haematocrit. Plasma proteins were separated and measured by the method of Gornall and others (1949). Results were analysed by standard statistical methods; differences likely to have arisen by chance in less than 5 per cent. of trials were considered significant.

\section{Subjects}

The subjects included eighteen women and seven men? with peripheral rheumatoid arthritis, six men with? rheumatoid spondylitis, one man with peripheral rheuma $\vec{F}$ toid arthritis complicated by quiescent pulmonary tuber-? culosis and clinical amyloidosis, and ten women and one man who served as normal controls.

The patients had all shown characteristic changes of rheumatoid disease for more than 5 years, corresponding to Grades II and III severity of disease in the classification of the American Rheumatism Association (Steinbrocker? and others, 1949), and at the time of this study had elevate ed sedimentation rates and no evidence of other disease including other causes of anaemia. In addition, alf patients classified as suffering from peripheral rheumatoif arthritis had bilateral, clinical, and $x$-ray deformities oळ the hands, fingers, feet, and toes, amongst their other changes. All patients classified as suffering from rheumatoid spondylitis had clinical and $x$-ray changes im the spine and sacro-iliac joints. The patient with known amyloidosis and quiescent tuberculosis showed albuming uria and an enlarged spleen in addition to peripherat arthritis and pulmonary changes. All the arthritis subjects were hospital patients; their therapeutic regim\& included salicylates, rest in bed, and physiotherapy, buश none was receiving specific haematinic treatment. The four patients who were receiving cortisone acetate will bef discussed later. The normal subjects were members of the hospital staff or patients admitted for conditione unlikely to affect the blood volume. Tests were made in the morning with the subjects fasting. Apart fron the patient with amyloidosis, none had a palpable spleen

\section{Results}

(1) Comparison of the Evans' Blue and Congo Reß Methods for Measurement of Blood Volume.-The Evans' blue and congo red methods were compare in 22 subjects: nine women and seven men with perio pheral rheumatoid arthritis, five men with rheuma toid spondylitis, and one man with peripheral rheuo matoid arthritis and amyloidosis. The tests were spaced at intervals of approximately one weekô except in one man in whom they were applied simultaneously (see below). The results are showif in Table I (opposite).

Values for the Evans' blue tests have been arrangec. in order of increasing magnitude and with the excepN tion of the patient with amyloidosis, all fall within or slightly above the range of 2,261 to $2,72 \mathbb{V}$ $\mathrm{ml} . / \mathrm{sq}$. m., which is the range found in a series of normal female subjects to be discussed later, and $i \overline{2}$ consistent with other reported normal ranges fob this method. On the other hand, the total blooø్ volume as measured by the congo red method gave unexpectedly variable values, which, although ino some cases approximately the same as those obtaine $\vec{P}$ by the Evans' blue method, in most cases were mucli higher (Table I). It was thought that some facto $\mathbb{B}$ 
TABLE I

COMPARISON OF TOTAL BLOOD VOLUMES PER UNIT SURFACE AREA (1./m.2) CALCULATED FROM DILUTION OF EVANS' BLUE WITH THOSE CALCULATED FROM DILUTION OF CONGO RED

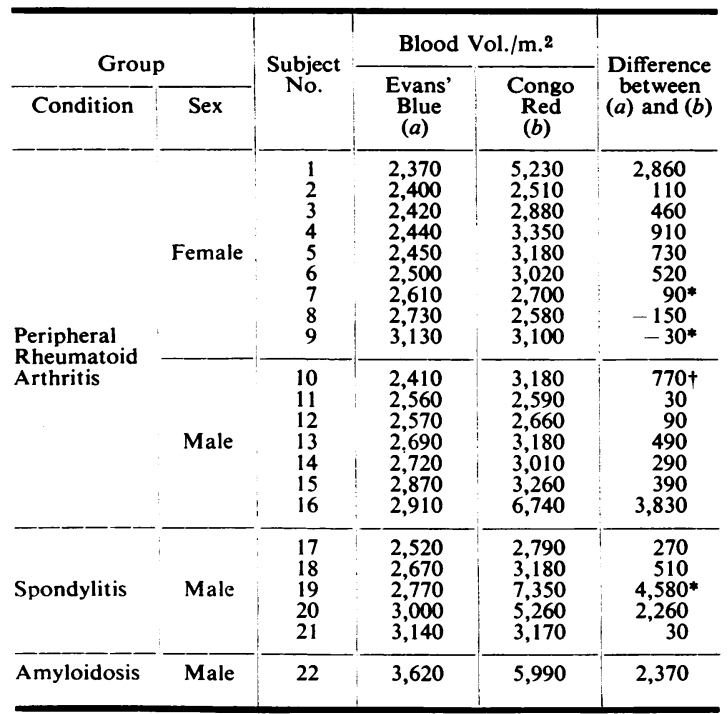

* Patients 7, 9, and 19 were receiving $50,37 \cdot 5$, and $100 \mathrm{mg} . / \mathrm{day}$ cortisone acetate orally respectively.

$\dagger$ In this patient both dye methods were used simultaneously.

in the blood of rheumatoid arthritis patients might cause the large variation in the apparent initial dilution of the congo red by interfering with the colour of the dye when mixed with plasma. This was tested by taking freshly-drawn heparinized plasma from twelve patients with typical rheumatoid arthritis of all grades of severity. Each sample was diluted to 10 per cent. with normal saline, to which congo red dye had been added to reach a final concentration of $1 \mathrm{mg}$. in $2,500 \mathrm{ml}$. The optical density of the dyed plasma was compared with that of the same plasma diluted with saline only. Despite variation in the icteric index and hydrogen ion concentration of the plasma samples, the optical density of the dye was almost identical for all twelve.

(2) Plasma Retention of Congo Red and Evans' Blue in Rheumatoid Arthritis.- The amount of dye retained at the end of one hour was compared for both dyes for the same series of patients, excluding the patient with clinical amyloidosis. The mean retention of Evans' blue after one hour was 86.1 \pm S.D. $1 \cdot 2$ per cent. The mean retention of congo red after one hour was $55 \pm$ S.D. 10.2 per cent. The means are significantly different.

The following pairs of variables were examined and no significant correlation found:
$A$ against $B, C, D, E, G, H$, and
$B$ against $\mathrm{C}, \mathrm{D}, \mathrm{E}, \mathrm{G}, \mathrm{H}$, and $\mathrm{I}$
$C$ against $F$

$A=$ rate of loss of Evans' blue from plasma.

B $=$ rate of loss of congo red from plasma.

$\mathrm{C}=$ activity of disease as measured by sedimentation rate.

$\mathrm{D}=$ blood volume per sq. $\mathrm{m}$. body surface as measured by Evans' blue method.

$\mathbf{E}=$ blood volume per sq. $\mathrm{m}$. body surface as measured by congo red method.

F = discrepancy between two methods for measuring blood volume per sq. $\mathrm{m}$

$\mathbf{G}=$ plasma protein concentration.

$\mathbf{H}=$ plasma albumin concentration.

I = plasma globulin concentration.

Thus the tendency of congo red to leave the vascular system of some patients at a rapid rate is not explained in terms of association with any one of these other variables. Conversely, there is no evidence that this tendency in any way affects the Evans' blue method for measuring blood volume in this disease.

The patient with amyloidosis lost congo red from his plasma at a rapid rate, i.e. a half-disappearance time of $4 \mathrm{~min}$., compared with about $65 \mathrm{~min}$. for uncomplicated rheumatoid arthritis, and no dye was detectable in his plasma after $30 \mathrm{~min}$. The same patient showed a fairly high one-hour retention of Evans' blue in his plasma, but the four values for optical density of this patient's plasma did not fall on a straight line when plotted on semilog paper against time. The curve indicated a rapid initial rate of loss of dye followed by a slower rate of loss after 10 min., as noted by Unger and others (1948).

In a man aged 29 who had peripheral rheumatoid arthritis with knee effusions, the two dyes were injected intravenously at the same time. Preliminary experiments in vitro had determined the small corrections needed for mutual interference of the dyes in the spectrophotometer. The one-hour plasma retention of congo red was 61 per cent., and that of Evans' blue was 92 per cent. Neither dye was detectable in the joint fluid after one hour. $24 \mathrm{hrs}$ later, no congo red was detectable in the plasma, but a trace was found in the joint fluid; on the other hand 33 per cent. of the Evans' blue still remained in the plasma at this time, and its concentration in the joint fluid was approximately half that in the plasma.

In one other patient with a knee joint effusion, no Evans' blue dye was found in the synovial fluid at the end of one hour, though approximately one-tenth of the initial plasma concentration was found in both fluid and plasma on the following day.

(3) Repeatability of Congo Red Retention Test.In two patients the congo red test was repeated after one week because the first test was technically unsatisfactory. Since congo red may be retained by amyloid-containing tissues for considerable periods of time after injection ( 2 months in a patient reported by Hass and Schulz, 1940), it has therefore been assumed by some that one congo red test will interfere with a second, presumably because the amyloidcontaining tissues are saturated with the dye. This is not true for normal subjects (Rowntree and others, 
1929), nor for the rheumatoid arthritis patients exemplified in Table II.

TABLE II

REPEATABILITY OF CONGO RED RETENTION TEST

\begin{tabular}{c|c|c|c|c}
\hline \multirow{2}{*}{$\begin{array}{c}\text { Subject } \\
\text { No. }\end{array}$} & $\begin{array}{c}\text { Interval } \\
\text { between } \\
\text { Tests }\end{array}$ & $\begin{array}{c}\text { Congo Red Retention } \% \\
\end{array}$ & $\begin{array}{c}\text { 1st Test } \\
\text { 2nd Test }\end{array}$ & $\begin{array}{c}\text { Change } \\
\text { per cent. }\end{array}$ \\
\hline 1 & 2 hrs & 76 & 84 & +8 \\
2 & 2 hrs & 72 & 70 & -2 \\
3 & 3 hrs & 54 & 57 & +3 \\
4 & 1 day & 46 & 62 & +16 \\
5 & 2 days & 72 & 77 & +5 \\
6 & 3 days & 48 & 50 & +2 \\
7 & 9 days & 61 & 61 & -5 \\
8 & 14 days & 38 & 33 & -3 \\
9 & 21 days & 33 & 30 & +7 \\
10 & 1 mth & 32 & 39 & +3 \\
11 & 4 mths & 60 & 63 & +3 \\
\hline
\end{tabular}

Average change $=+3 \cdot 1( \pm 5 \cdot 6)$ per cent.

The following experiment done in this laboratory in 1946 is presented as further evidence against the possibility of "saturation" of the dye clearance mechanism.

A dilute solution of congo red in 5 per cent. dextrose solution was infused intravenously into one patient (who had peripheral rheumatoid arthritis without amyloidosis) on 3 days, giving a total of nine half-hour intervals, during which the infusion rate was kept approximately constant and observations on the plasma concentration of congo red were made (allowing at least $7 \mathrm{~min}$. for equilibration). The total volume infused did not exceed $150 \mathrm{ml}$. in 2 hours and dilution effects have accordingly been disregarded. The results are tabulated in Table III.

TABLE III

CONGO RED BLOOD LEVELS ATTAINED AFTER 30-MIN PERIODS OF INTRAVENOUS INFUSION AT A CONSTANT RATE

\begin{tabular}{|c|c|c|c|c|c|}
\hline \multirow[b]{2}{*}{ Day } & \multirow{2}{*}{$\begin{array}{l}\frac{1}{2} h r \\
\text { Period }\end{array}$} & \multirow{2}{*}{$\begin{array}{l}\text { Rate of } \\
\text { Congo Red } \\
\text { Infusion } \\
\text { (mg./min.) }\end{array}$} & \multicolumn{2}{|c|}{ Serum Level } & \multirow{2}{*}{$\begin{array}{c}\text { Change } \\
\text { per } \\
\text { cent. }\end{array}$} \\
\hline & & & $\begin{array}{c}\text { After Initial } \\
\text { Equilibration }\end{array}$ & $30 \mathrm{At}$ min. & \\
\hline 1 & $\begin{array}{l}1 \\
2 \\
3 \\
4\end{array}$ & $\begin{array}{l}1 \cdot 03 \\
1 \cdot 13 \\
1 \cdot 18 \\
1 \cdot 15\end{array}$ & $\begin{array}{l}0.083 \\
0.068 \\
0.073 \\
0.069\end{array}$ & $\begin{array}{l}0.068 \\
0.073 \\
0.069 \\
0.076\end{array}$ & $\begin{array}{r}-18 \\
+7 \\
-6 \\
+10\end{array}$ \\
\hline 4 & $\begin{array}{l}1 \\
2 \\
3\end{array}$ & $\begin{array}{l}0.64 \\
0.64 \\
0.99\end{array}$ & $\begin{array}{l}0.100 \\
0.081 \\
0.069\end{array}$ & $\begin{array}{l}0.081 \\
0.070 \\
0.071\end{array}$ & $\begin{array}{l}-19 \\
-14 \\
+\quad 2\end{array}$ \\
\hline 11 & $\frac{1}{2}$ & $\begin{array}{l}0.99 \\
2.75\end{array}$ & $\begin{array}{l}0 \cdot 113 \\
0 \cdot 122\end{array}$ & $\begin{array}{l}0 \cdot 103 \\
0 \cdot 134\end{array}$ & $\begin{array}{r}-9 \\
+10\end{array}$ \\
\hline
\end{tabular}

Thus, although there is variation from day to day as regards the plasma congo red concentration achieved by a given rate of infusion, there is no consistent increase between the start and end of each period, as might be expected if the congo red clearance mechanism becomes progressively "saturated".
(4) Comparison of Evans' Blue Retention in Normal 3 and Arthritic Subjects.-A second series of subjects 므. included ten women and two men with peripheral $\stackrel{?}{?}$ rheumatoid arthritis and ten normal women and one $\overrightarrow{\vec{F}}$ normal man who served as controls. The dyemethod being the same as previously used, the $\frac{}{\circ}$ values for the one-hour retention of Evans' blue $\frac{\bar{\sigma}}{\bar{s}}$ obtained in the normal subjects of this series can be $\widehat{\nabla}$ compared with the arthritis patients in both series. ㅇ For a uniform group of eighteen women with peri- $\omega$ pheral rheumatoid arthritis the mean dye retention $\overrightarrow{0}$ was $87 \cdot 7 \pm$ S.D. 1.6 per cent. For nine normal $\overrightarrow{\mid}$ women in the same age range the mean dye retention $\omega_{\sigma}$ was $95.6 \pm$ S.D. 1.6 per cent. The difference@ between the means ( 7.9 per cent.) exceeded twice its? standard error $(2 \cdot 2$ per cent.) and is significant. $\vec{P}$ Two results (in one normal woman and in one $-\overrightarrow{-}$ patient) have been excluded from the calculation since in them the slope of the line from which the one-hour retention was calculated depended on only two points. These values are not materially altered $\overline{3}$ if the results in all the arthritis subjects are compared $\stackrel{0}{\circ}$ with all the controls without exclusions for sex or ${ }^{3}$ completeness of data.

(5) Comparison of Evans' Blue and Tagged Red Cell (Sodium Chromate ${ }^{51} \mathrm{Cr}$ ) Methods of Measuring Blood Volume in Patients and Controls.-Table IV (opposite) compares blood volume measured simultaneously by Evans' blue and tagged red cell ${ }_{\circ}^{\circ}$ methods in the same 23 subjects. The Evans' blue $\underset{F}{\vec{A}}$ value is consistently greater than ${ }^{51} \mathrm{Cr}$ value, but the $\frac{O}{3}$ ratio $\frac{\text { Blood volume (tagged red cell method) }}{\text { Blood volume (Evans' blue method) }}$ is not significantly different for patients as compared with controls. Results for the three male subjects are given in Table IV, but are not included in the statistical comparison.

(6) Comparison of Red Cell Mass, Plasma Volume, and Total Blood Volume for Patients and윽 Controls.- In this part of the study the figure for the $>$ total blood volume is the "true" blood volume, i.e. the sum of the plasma volume (Evans' blue) and $\bar{N}$ the red cell mass $\left({ }^{51} \mathrm{Cr}\right)$. The comparison is limited ${ }^{\circ}$ to the ten women with arthritis and the ten control ${ }^{N}$ women of the second series. As would be expected, the women with arthritis were more anaemic thano the controls (the venous haematocrit is given ino Table V). The two groups did not differ significantly as regards age (Table IV). All the patients? and eight out of ten of the controls were recumbent 0 at the time of the test, but seven patients and two controls had been in bed for more than one week. $\stackrel{\mathbb{D}}{\circ}$ Recumbency causes a slight increase in blood $\overrightarrow{\mathbb{Q}}$ 
TABLE IV

BLOOD VOLUMES IN TEN WOMEN AND TWO MEN WITH PERIPHERAL RHEUMATOID ARTHRITIS AND IN TEN NORMAL WOMEN AND ONE NORMAL MAN ESTIMATED SIMULTANEOUSLY BY THE EVANS' BLUE AND 51CR METHODS

\begin{tabular}{|c|c|c|c|c|c|c|c|c|c|c|c|c|}
\hline \multirow[b]{2}{*}{ Sex } & \multirow{2}{*}{$\begin{array}{l}\text { Subject } \\
\text { No. }\end{array}$} & \multirow[b]{2}{*}{$\begin{array}{l}\text { Age } \\
\text { (yrs) }\end{array}$} & \multirow[b]{2}{*}{$\begin{array}{c}\text { Body- } \\
\text { Weight } \\
\text { (kg.) }\end{array}$} & \multirow[b]{2}{*}{$\begin{array}{c}\begin{array}{c}\text { Surface } \\
\text { Area }\end{array} \\
\text { (sq. m.) }\end{array}$} & \multirow{2}{*}{$\begin{array}{c}\text { Haema- } \\
\text { tocrit } \\
\text { (cor- } \\
\text { rected) } \\
\text { (per } \\
\text { cent.) }\end{array}$} & \multirow{2}{*}{$\begin{array}{c}\begin{array}{c}\text { Duration } \\
\text { of } \\
\text { Recum- } \\
\text { bency }\end{array} \\
\end{array}$} & \multicolumn{2}{|c|}{$\begin{array}{c}\text { Rheumatoid } \\
\text { Arthritis }\end{array}$} & \multirow{2}{*}{$\begin{array}{l}\text { Diagnosis of } \\
\text { Normal Subjects }\end{array}$} & \multicolumn{2}{|c|}{$\begin{array}{l}\text { Total Blood } \\
\text { Volume (ml.) }\end{array}$} & \multirow{2}{*}{$\begin{array}{r}\text { Ratio } \\
(a) /(b)\end{array}$} \\
\hline & & & & & & & $\begin{array}{c}\text { Dura- } \\
\text { tion } \\
\text { (yrs) }\end{array}$ & $\begin{array}{c}\text { Sedi- } \\
\text { menta- } \\
\text { tion Rate } \\
(\mathrm{mm} . / \\
\text { min.) }\end{array}$ & & $\begin{array}{c}\text { Evans' } \\
\text { Blue } \\
\text { (ml.) } \\
\text { (a) }\end{array}$ & $\begin{array}{l}{ }^{51 C r} \\
\underset{(b)}{(m l .)}\end{array}$ & \\
\hline \multirow{8}{*}{ Female } & $\begin{array}{r}1 \\
2 \\
3 \\
4 \\
5 \\
6 \\
7 \\
8 \\
9 \\
10\end{array}$ & $\begin{array}{l}64 \\
38 \\
59 \\
64 \\
66 \\
51 \\
63 \\
48 \\
58 \\
52\end{array}$ & $\begin{array}{l}47 \cdot 3 \\
48 \cdot 8 \\
43 \cdot 2 \\
55 \cdot 4 \\
55 \cdot 4 \\
54 \cdot 3 \\
59 \cdot 5 \\
46 \cdot 4 \\
40 \cdot 3 \\
56 \cdot 4\end{array}$ & $\begin{array}{l}1.43 \\
1.49 \\
1.37 \\
1.56 \\
1.56 \\
1.58 \\
1.60 \\
1.44 \\
1.36 \\
1 \cdot 58\end{array}$ & $\begin{array}{l}42 \cdot 8 \\
42 \cdot 3 \\
37 \cdot 4 \\
33 \cdot 8 \\
33 \cdot 6 \\
42 \cdot 1 \\
28 \cdot 7 \\
37 \cdot 2 \\
35 \cdot 2 \\
39 \cdot 6\end{array}$ & $\begin{array}{l}3 \text { mths } \\
6 \text { mths } \\
3 \text { wks } \\
2 \text { wks } \\
1 \text { hr } \\
5 \text { wks } \\
11 \text { wk } \\
4 \text { wks } \\
2 \text { yrs } \\
3 \text { wks }\end{array}$ & $\begin{array}{r}55 \\
13 \\
10 \\
15 \\
8 \\
6 \\
15 \\
15 \\
15 \\
12\end{array}$ & $\begin{array}{l}1 \cdot 29 \\
1.51 \\
0.68 \\
1.25 \\
1.08 \\
1.27 \\
1.35 \\
1.34 \\
0.69 \\
1 \cdot 29\end{array}$ & & $\begin{array}{l}4,130 \\
3,890 \\
3,520 \\
4,410 \\
4,440 \\
3,670 \\
4,380 \\
4,490 \\
3,370 \\
5,230\end{array}$ & $\begin{array}{l}3,360 \\
3,430 \\
3,200 \\
3,620 \\
4,170 \\
3,430 \\
4,270 \\
3,330 \\
2,950 \\
4,300\end{array}$ & $\begin{array}{l}0.81 \\
0.88 \\
0.91 \\
0.82 \\
0.94 \\
0.93 \\
0.97 \\
0.74 \\
0.88 \\
0.82\end{array}$ \\
\hline & Mean & $56 \cdot 3$ & $50 \cdot 7$ & 1.497 & $36 \cdot 255$ & & $10 \cdot 4$ & & & 4,153 & 3,604 & 0.871 \\
\hline & $\begin{array}{c}\text { Standard } \\
\text { Deviation }\end{array}$ & $8 \cdot 9$ & $6 \cdot 1$ & 0.091 & $4 \cdot 43$ & & & & & 558 & 475 & 0.071 \\
\hline & $\begin{array}{l}11 \\
12 \\
13 \\
14 \\
15 \\
16 \\
17 \\
18 \\
19 \\
20\end{array}$ & $\begin{array}{l}64 \\
49 \\
37 \\
40 \\
41 \\
55 \\
76 \\
46 \\
43 \\
35\end{array}$ & $\begin{array}{l}60 \cdot 5 \\
78 \cdot 6 \\
52 \cdot 9 \\
48 \cdot 2 \\
45 \cdot 4 \\
52 \cdot 5 \\
68 \cdot 6 \\
58 \cdot 0 \\
63 \cdot 5 \\
72 \cdot 3\end{array}$ & $\begin{array}{l}1.65 \\
1.93 \\
1.37 \\
1.44 \\
1.39 \\
1.82 \\
1.83 \\
1.62 \\
1.63 \\
1.80\end{array}$ & $\begin{array}{l}41 \cdot 9 \\
41 \cdot 0 \\
42 \cdot 4 \\
41 \cdot 9 \\
40 \cdot 5 \\
42 \cdot 7 \\
41 \cdot 8 \\
45 \cdot 8 \\
40 \cdot 1 \\
41 \cdot 5\end{array}$ & $\begin{array}{l}2 \text { hrs } \\
\text { Ambulant } \\
5 \text { hrs } \\
5 \text { hrs } \\
3 \text { days } \\
9 \text { days } \\
2 \text { wks } \\
5 \text { hrs } \\
3 \text { days } \\
\text { Ambulant }\end{array}$ & 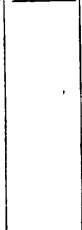 & & $\begin{array}{l}\text { Prurigo } \\
\text { Normal } \\
\text { Neurosis } \\
\text { Neurosis } \\
\text { Parotid tumour } \\
\text { Mild diabetes } \\
\text { Cataract } \\
\text { ? Cholelithiasis } \\
\text { Dermatitis of hands } \\
\text { Dermatitis of hands }\end{array}$ & $\begin{array}{l}4,490 \\
5,120 \\
4,100 \\
3,770 \\
3,650 \\
4,430 \\
4,140 \\
3,790 \\
3,800 \\
4,350\end{array}$ & $\begin{array}{l}3,850 \\
4,660 \\
3,480 \\
3,270 \\
3,140 \\
3,380 \\
3,790 \\
3,690 \\
3,590 \\
3,950\end{array}$ & $\begin{array}{l}0.86 \\
0.91 \\
0.85 \\
0.87 \\
0.86 \\
0.76 \\
0.92 \\
0.98 \\
0.94 \\
0.91\end{array}$ \\
\hline & Mean & $48 \cdot 6$ & $62 \cdot 0$ & $1 \cdot 668$ & $41 \cdot 95$ & & & & & 4,164 & 3,680 & 0.885 \\
\hline & $\begin{array}{c}\text { Standard } \\
\text { Deviation }\end{array}$ & $15 \cdot 2$ & $10 \cdot 9$ & $0 \cdot 176$ & $1 \cdot 57$ & & & & & 452 & 432 & 0.059 \\
\hline & $\begin{array}{l}\text { Difference } \\
\text { between } \\
\text { Means }\end{array}$ & $+7 \cdot 7$ & $-11 \cdot 3 *$ & $-0 \cdot 171$ & $-5 \cdot 699^{*}$ & & & & & $-10 \cdot 6$ & $-75 \cdot 7$ & -0.014 \\
\hline & $\begin{array}{l}\text { S.E. of } \\
\text { Difference }\end{array}$ & $\pm 5 \cdot 6$ & $\pm 4 \cdot 0 *$ & $\pm 0 \cdot 0627 *$ & $\pm 1 \cdot 488 *$ & & & & & \pm 227 & \pm 203 & \pm 0.029 \\
\hline \multirow{2}{*}{ Male } & $\begin{array}{l}21 \\
22\end{array}$ & $\begin{array}{l}69 \\
56\end{array}$ & $\begin{array}{l}73 \cdot 4 \\
64 \cdot 0\end{array}$ & $\begin{array}{l}1 \cdot 86 \\
1 \cdot 73\end{array}$ & $\begin{array}{l}40 \cdot 2 \\
40 \cdot 5\end{array}$ & $\begin{array}{l}2 \text { wks } \\
3 \text { wks }\end{array}$ & $\begin{array}{l}5 \\
6\end{array}$ & $\begin{array}{l}0 \cdot 67 \\
1 \cdot 57\end{array}$ & & $\begin{array}{l}5,280 \\
6,200\end{array}$ & $\begin{array}{l}4,750 \\
4,400\end{array}$ & $\begin{array}{l}0 \cdot 90 \\
0 \cdot 71\end{array}$ \\
\hline & 23 & 32 & $71 \cdot 8$ & $1 \cdot 80$ & $45 \cdot 5$ & Ambulant & & 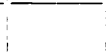 & Normal & 5,390 & 4,480 & 0.83 \\
\hline
\end{tabular}

volume (Thompson and others, 1928; Waterfield, 1931), but prolonged recumbency causes a decrease (Deitrick and others, 1948). The two groups differed significantly in body-weight (Line 1, Table V, overleaf).

Fig. 1 (overleaf) shows weight plotted against total blood volume per $\mathrm{kg}$. Since there is a significant negative regression for this relationship (i.e. the lighter the subject the greater the blood volume per $\mathrm{kg}$.), the greater total blood volume per $\mathrm{kg}$., for the patients (Table V) might arise because the patients were lighter than the controls.

The two groups also differ significantly in their surface areas, but surface area plotted against blood volume per sq. $\mathrm{m}$. shows no significant regression (Fig. 2, overleaf).
Surface area is therefore more likely to be a valid standard of reference for comparing the two groups. However, estimates of surface area depend on height, which was difficult to measure accurately in our deformed patients. The most satisfactory comparison is obtained by a statistical method which allows for difference in body-weight.

The relationship of blood volume to body-weight for all subjects is best represented by the mean regression line (Fig. 3, overleaf).*

Analysis of covariance compares the two groups on the basis of their variation about this line, and at the same time estimates the likelihood

\footnotetext{
* The finding that blood volume per $\mathrm{kg}$. increases as body-weight decreases is illustrated by this regression line, which, if retropolated, has a positive value for blood volume at zero body-weight.
} 
COMPARISON OF (a) PLASMA VOLUME (EVANS' BLUE), (b) RED CELL MASS (51Cr) AND BLOOD VOLUMĒ (a+b) IN TEN NORMAL WOMEN AND TEN WOMEN WITH PERIPHERAL RHEUMATOID ARTHRITIS

\begin{tabular}{|c|c|c|c|c|c|c|}
\hline \multirow{3}{*}{$\begin{array}{l}\text { Standard } \\
\text { of } \\
\text { Comparison }\end{array}$} & \multicolumn{4}{|c|}{ Women } & \multirow{3}{*}{$\begin{array}{l}\text { Difference } \\
\text { between } \\
\text { Means }\end{array}$} & \multirow{3}{*}{$\begin{array}{c}\text { Standard } \\
\text { Error of } \\
\text { Difference }\end{array}$} \\
\hline & \multicolumn{2}{|c|}{ Ten Arthritic } & \multicolumn{2}{|c|}{ Ten Normal } & & \\
\hline & Mean & $\begin{array}{l}\text { Standard } \\
\text { Deviation } \\
\quad \pm\end{array}$ & Mean & $\begin{array}{l}\text { Standard } \\
\text { Deviation } \\
\pm\end{array}$ & & \\
\hline $\begin{array}{llll}\text { Body-weight (kg.). } & \ldots & \ldots & \ldots\end{array}$ & $50 \cdot 7$ & $6 \cdot 1$ & $62 \cdot 0$ & $10 \cdot 9$ & $-11 \cdot 3^{*}$ & $4 \cdot 0$ \\
\hline Surface Area (sq. m.) $\quad \ldots \quad \ldots$ & $1 \cdot 50$ & $0 \cdot 091$ & $1 \cdot 67$ & $0 \cdot 176$ & $-\mathbf{0} \cdot 17^{*}$ & 0.063 \\
\hline $\begin{array}{l}\text { Plasma vol. (ml.) } \ldots \text {. } \ldots \text {. } \\
\text { Plasma vol./Body-weight (ml./kg.) } \\
\text { Plasma vol./Surface area (ml./sq. m.) }\end{array}$ & $\begin{array}{c}2,650 \\
52 \cdot 4 \\
1,770\end{array}$ & $\begin{array}{l}396 \\
204\end{array}$ & $\begin{array}{l}2,420 \\
39 \cdot 6 \\
1,450\end{array}$ & $\frac{278}{5 \cdot 02}$ & $\begin{array}{l}+240 \\
+12 \cdot 8^{*} \\
+320^{*}\end{array}$ & $\begin{array}{c}156 \\
2 \cdot 32 \\
73 \cdot 4\end{array}$ \\
\hline $\begin{array}{l}\text { Red Cell vol. (ml.) } \\
\text { Red Cell vol./Body-weight }(\mathrm{ml} . / \mathrm{kg} .) \\
\text { Red Cell vol./Surface area }(\mathrm{ml} . / \mathrm{sq} . \mathrm{m} .)\end{array}$ & $\begin{array}{l}1,300 \\
25 \cdot 8 \\
868\end{array}$ & $\begin{array}{r}195 \\
3 \cdot 27 \\
110\end{array}$ & $\begin{array}{c}1,540 \\
25 \cdot 3 \\
927\end{array}$ & $\begin{array}{c}182 \\
2 \cdot 09 \\
70 \cdot 9\end{array}$ & $\begin{array}{l}-240^{*} \\
+0 \cdot 5 \\
-59\end{array}$ & $\begin{array}{c}84 \cdot 2 \\
1 \cdot 44 \\
132\end{array}$ \\
\hline $\begin{array}{l}\text { Total Blood vol. (P.V. + R.C.V.) (ml.) } . \\
\text { Total Blood vol./Body-weight (ml./kg.). } \\
\text { Total Blood vol./Surface area (ml./sq. m.) }\end{array}$ & $\begin{array}{l}3,950 \\
78 \cdot 2 \\
2,640\end{array}$ & $\begin{array}{l}496 \\
632 \\
232\end{array}$ & $\begin{array}{l}3,960 \\
64 \cdot 9 \\
2,380\end{array}$ & $\begin{array}{r}422 \\
7 \cdot 50\end{array}$ & $\begin{aligned} & -10 \\
+ & 13 \cdot 3^{*} \\
+ & 260 *\end{aligned}$ & $\begin{array}{r}206 \\
3 \cdot 1 \\
86 \cdot 2\end{array}$ \\
\hline $\begin{array}{l}\text { Body Haematocrit } \\
\qquad\left(\frac{6}{3+6} \times 100\right) \text { (per cent.) } \ldots \\
\text { Corrected Venous Haematocrit } \\
\text { (per cent.) } \ldots \\
\text { Body/Venous Haematocrit Ratio }\end{array}$ & $\begin{array}{l}36 \cdot 3 \\
0 \cdot 912\end{array}$ & $\begin{array}{l}4 \cdot 34 \\
0 \cdot 048\end{array}$ & $\begin{array}{l}42 \cdot 0 \\
0.932\end{array}$ & $\begin{array}{l}1 \cdot 57 \\
0 \cdot 037\end{array}$ & $\begin{array}{ll}- & 5 \cdot 7 \\
- & 0.0198\end{array}$ & $\begin{array}{l}1 \cdot 44 \\
1.46 \\
0.055\end{array}$ \\
\hline
\end{tabular}

that the differences observed had arisen by chance. The method has been applied to the covariances of

(1) weight and red cell mass,

(2) weight and plasma volume,

(3) weight and total blood volume.

The third relationship is illustrated in Fig. 3; this is a scattergram of the values for weight and total blood volume, in which the slopes of the mean regression lines for patients and controls are not significantly different, hence a comparison of the two sub-groups about the regression line for all

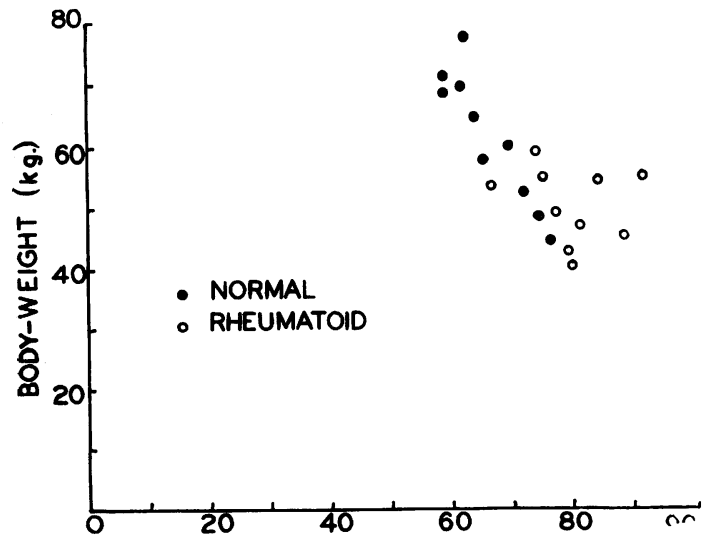

BLOOD VOLUME / UNIT BODY-WEIGHT(ml./kg.)

Fig. 1.-Blood volume per unit body-weight related to body-weight. the subjects is valid. This line has been drawn in and represents the equation:

$$
\text { Blood volume }(\mathrm{ml} .)=3956.65+39.84 \times
$$$$
\text { (body-weight (kg.)-55.38). }
$$

Fig. 3(a) shows how the means of the two sub groups differ both in weight and in blood volume They have consequently been adjusted to the point

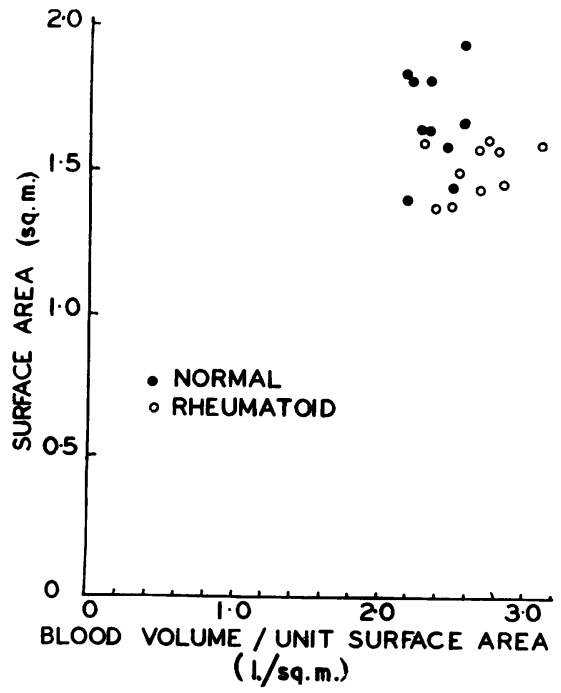

Fig. 2.-Blood volume per unit surface area related to surface are.

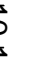




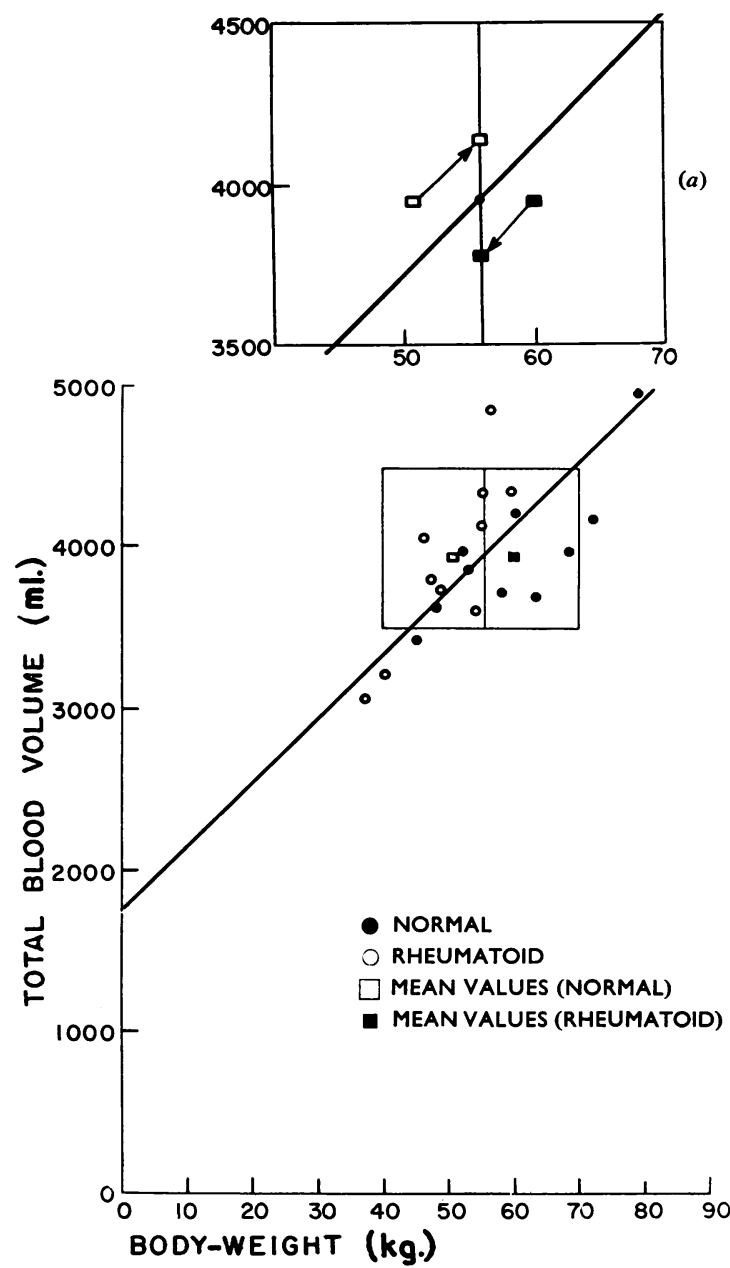

Fig. 3.-Body-weight related to blood volume. The slope is the regression line for all observations. Enlarged inset (a) shows how the means of controls and rheumatoid subjects differ in body-weight and blood volume.

corresponding to the average weight of the subjects as a whole by moving them parallel to the mean regression line. When this is done and the two groups are compared for the values they would have had if they had been of equal weight, it is found that the arthritis subjects have a greater total blood volume than the controls, and the difference, as judged by the " $t$ " test, is significant.

Table VI summarizes the results for the three relationships.

TABLE VI

ADJUSTED MEAN VALUES FOR RED CELL MASS, PLASMA VOLUME, AND BLOOD VOLUME IN TEN NORMAL WOMEN AND TEN WOMEN WITH PERIPHERAL RHEUMATOID ARTHRITIS

(Adjusted mean values for volumes)

\begin{tabular}{|c|c|c|c|c|}
\hline $\begin{array}{l}\text { Measure } \\
\text { of } \\
\text { Volume }\end{array}$ & Arthritics & Normals & $\begin{array}{l}\text { Differ- } \\
\text { ence } \\
\pm \text { S.D. }\end{array}$ & 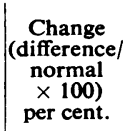 \\
\hline 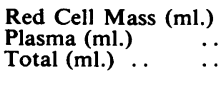 & $\begin{array}{l}1,370 \\
2,770 \\
4,140\end{array}$ & $\begin{array}{l}1,470 \\
2,300 \\
3,780\end{array}$ & $\begin{array}{l}100 \pm 72 \\
470 \pm 44^{*} \\
360 \pm 52^{*}\end{array}$ & $\begin{array}{l}-7 \cdot 1 \\
+20 \cdot 4 \\
+9 \cdot 6\end{array}$ \\
\hline
\end{tabular}

* The difference is significant.

We conclude that the chief cause of the anaemia in our patients was 20.4 per cent. rise in the plasma volume, which was statistically significant. An average fall of $7 \cdot 1$ per cent. in the red cell mass failed to reach significance levels. The total blood volume of the arthritis patients showed an average significant rise of 9.6 per cent. Thus our patients showed a hypervolaemic normocythaemia.

Serial Simultaneous Blood Volume Measurements in one Arthritic Patient.-A man of 32 years with rheumatoid spondylitis of 8 years' duration exhibited chiefly involvement of the spine and hips. He had been maintained in reasonably good remission for 3 years on $75 \mathrm{mg}$. cortisone acetate orally per day. On this therapy he was not anaemic and had a normal or only slightly elevated sedimentation rate, despite residual bony deformities with some pain. During the period of this study his regime and diet were constant. The observations made on the plasma volume and red cell mass were performed before and after the abrupt discontinuation of a cortisone acetate on Day 4 (Table VII).

24 hours after withdrawal of the hormone the patient experienced a recurrence of the symptoms and signs of arthritis, accompanied by a reduction in the proportion of haemoglobin and erythrocytes in the peripheral blood, without reduction of red cell mass, other than that which could be accounted for as cells (about $90 \mathrm{ml}$.) removed with blood samples drawn for concurrent metabolic studies.

TABLE VII

VALUES FOR A PATIENT WITH RHEUMATOID SPONDYLITIS BEFORE AND AFTER WITHDRAWAL OF CORTISONE ACETATE THERAPY

\begin{tabular}{|c|c|c|c|c|c|c|}
\hline Day No. & $\begin{array}{c}\text { Plasma Volume } \\
\text { (Evans' Blue) } \\
\text { (ml.) }\end{array}$ & $\begin{array}{l}\text { Red Cell Mass } \\
\text { (5lCr) } \\
(\mathrm{ml} .)\end{array}$ & $\begin{array}{l}\text { Total } \\
\text { Volume } \\
\text { (ml.) }\end{array}$ & $\underset{\text { Baematocrit }}{\text { Body cent.) }}$ & $\begin{array}{l}\text { Corrected Venous } \\
\text { Haematocrit } \\
\text { (per cent.) }\end{array}$ & $\begin{array}{c}\text { Body/Venous } \\
\text { Haematocrit } \\
\text { Ratio }\end{array}$ \\
\hline 11 & $\begin{array}{l}1,940 \\
2,230\end{array}$ & $\begin{array}{l}1,390 \\
1,300\end{array}$ & $\begin{array}{l}3,330 \\
3,530\end{array}$ & $\begin{array}{l}41 \cdot 8 \\
36 \cdot 9\end{array}$ & $\begin{array}{l}45 \cdot 2 \\
38 \cdot 6\end{array}$ & $\begin{array}{l}0.925 \\
0.955\end{array}$ \\
\hline Change & +290 & -90 & +200 & $-4 \cdot 9$ & $-6 \cdot 6$ & - \\
\hline
\end{tabular}




\section{Discussion}

The dye retention results confirm our past experience, namely, that intravenously-injected congo red is removed abnormally rapidly from the blood stream of rheumatoid arthritis patients. The significance of this is not obvious. At least six mechanisms may influence the removal of dyes from the blood stream:

(1) biliary excretion (Smith, 1925),

(2) urinary excretion,

(3) reticulo-endothelial system (Cruickshank and Whitfield, 1944),

(4) dispersion of dye outside the vascular system because of increased capillary permeability,

(5) tissue fixation of dyes (possibly by a sub-clinical level of amyloidosis or other alteration of connective tissue),

(6) increased loss through a change in the dye-protein binding of constituents of the blood stream.

We have no evidence favouring either (1) or (3). Urinary excretion of congo red dye in the first hour was not detected in these studies or by others (Unger and others, 1948). Smith (1925) found that vital red dye stained the cervical lymph in dogs soon after intravenous injection. Both lymph flow (Drinker and Field, 1933) and capillary permeability (Krogh, 1930) are increased in inflammation, whatever its cause, and in rheumatoid arthritis the inflamed synovial membrane tends to permit the passage into the synovial fluid of increased amounts of macromolecules such as plasma proteins, and even at times bacteria (Bauer and others, 1940). Nevertheless, the rate of movement of dye to the synovial fluid in the two cases studied suggests that it is unlikely that significant amounts of dye leave the blood stream by this route during the first hour after injection.

One possible exception is Case 22 (Table IV), in whom the Evans' blue dye method for measuring blood volume gave unexpectedly high results. This patient's arthritis was associated with marked and lifelong peripheral oedema of the type seen in Milroy's disease. Moreover, the rate of removal of Evans' blue dye from the blood stream in the patients was only slightly (although significantly) faster than in the controls. It is possible that the comparatively low rate of retention of congo red in the blood stream in arthritis subjects represents a subclinical level of amyloidosis or analogous alteration of the polysaccharide and protein constituents of connective tissue. Two points favour this interpretation. Firstly, amyloid has been found in the tissues of 24 per cent. of eighty patients with rheumatoid arthritis submitted to autopsy in this hospital (Bauer and Bennett, unpublished). In one of these congo red retention was in the 50-70 per cent. range shortly before death (Mass. Gen. 므. Hosp., 1948). Secondly, decreased congo red reten-. tion has been found in other patients who, although $\overrightarrow{\vec{\rho}}$ without clinical evidence of amyloidosis, did have? diseases which can be associated with this complication. However, in two patients in whom the $\frac{\bar{\sigma}}{\bar{c}}$ congo red retention was found to be 50 per cent, or less within 2 weeks of death, there was no gross or 0 histological evidence of amyloidosis at autopsyon despite using several staining techniques; one of these has been published (Mass. Gen. Hosp., 1941). Finally, we found no evidence for the possibility that $\vec{\rho}$ alteration in the plasma proteins might account for changes in dye-retention, or that a constituent of the⿳⺈. blood of rheumatoid arthritis patients might directly $\vec{A}$ alter the intensity of the colour of congo red dye.We leave unexplained the tendency of the congo red $\mathrm{G}$ method to measure an anomalously large plasmao volume in arthritis. It seems likely that part of the dye is rapidly removed from the circulation in somez patients during the first few minutes following injec- $\frac{0}{2}$ tion, and that the remainder is lost at a slower rate, $\stackrel{\bigcirc}{\Im}$ though more rapidly than the rate of loss of $\overrightarrow{0}$ Evans' blue dye. The one patient with amyloidosis s gave high blood volume values for both of these dye methods. In the absence of such complications, however, the Evans' blue method is reliable for measuring blood volume of both rheumatoido arthritis and normal subjects.

No attempt will be made to review the literature on blood volume measurement except to note thato estimates of the normal blood volume vary with the method employed. Methods depending on the dilution of labelled red blood cells give figures 10 to 20 per cent. lower than methods depending upon the dilution of a substance distributed in the plasma. Other sources of variation between laboratories 3 . include differences in such details as the type of haematocrit tube used, the time and force with which the blood is centrifuged, the correction for trappedo plasma, and the time that the tourniquet is left on the arm preparatory to venepuncture. Comparisonso also vary with the standard of reference: the use of body-weight, for example, may introduce errors,, because blood volume tends to be proportionately 0 higher in lighter subjects (Gibson and Evans, 1937; 证 Rowntree and others, 1929). For these reasons we compared the values for blood volume and its com $_{-0}$ ponent parts in rheumatoid arthritis subjects with those of a matched series of normal subjects in the same laboratory making a statistical correction for 0 body-weight differences: on the other hand we mayo. have introduced errors of sampling because of the relatively small numbers $(10+10)$ of patients and 
controls studied. We are aware that the method of comparison of normal and arthritis subjects is a major problem in numerical studies of this sort, and that the apparent result may be influenced markedly by the method or standards of reference chosen. It is of interest that of the three methods of comparison studied (volume per unit bodyweight, volume per unit surface area, and covariance of blood volume and body-weight), the method chosen is that which gives the smallest differences of blood volume and plasma volume between the two groups.

Few authors who have studied the normal blood volume by methods similar to those used here give their results in sufficient detail to enable one to distinguish subjects who are comparable to our normals for age and sex. Friedlander and coworkers (1935), using Evans' blue dye, found a mean blood volume of $80 \cdot 2 \mathrm{ml} / \mathrm{kg}$. for twenty women of mean age 41 , results which are probably too high, since they are well above the normal ranges reported by others. Gibson and Evans (1937), using the same method in a younger series of women whose average age was 31.5 years, found $61 \cdot 1 \mathrm{ml}$./ $\mathrm{kg}$. or 2.531 ./sq. m. Their older subjects had lower blood volumes (see Table VIII). For red cell tagging methods, Berlin and others (1951), using phosphorus ${ }^{32} \mathrm{P}$, reported $64.6 \mathrm{ml} . / \mathrm{kg}$. in a group of fifteen normal women of average age $31 \cdot 3$ years and average weight $55.7 \mathrm{~kg}$. No results for normal women have been published for the ${ }^{51} \mathrm{Cr}$ method.

Four reports are available on the blood volume in rheumatoid arthritis. Sparks and Haden (1932) used the congo red method and reported an increase compared with normal subjects. Robinson (1943) used phenol-tetra-brom-phthalein-sodium sulphate dye and came to the same conclusion. Garry (1952) used Evans' blue and found an increase in plasma volume and a decrease in red cell mass. His conclusions are weakened because the weights of his patients are all multiples of 5 or $10 \mathrm{~kg}$. The most comprehensive study of this subject is that of Jeffrey (1953), who used Evans' blue in a series of 52 patients with rheumatoid arthritis, and concluded that total blood volume was normal or reduced in this disease. He found a raised blood volume per unit weight in his thirty women patients, but attributed this to the loss of weight they had experienced rather than to an increase in blood volume. Their blood volume per unit surface area was not significantly increased. Jeffrey compared his results with the normal figures of other workers, chiefly Gibson and Evans (1937), which may have introduced an error due to differences in technique. Moreover, in normal women blood volume decreases as age increases (Gibson and Evans, 1937; Rowntree and others, 1929). Jeffrey does not state the age of his patients, but rheumatoid arthritis is commonest in women over 30 years of age, so that one would suspect that his arthritis patients were older than the normal subjects of Gibson and Evans, most of whom were younger than this.* Jeffrey's figures for blood volume/unit surface area are significantly greater than those for the ten oldest normal women in Gibson and Evans's series for whom surface area data are available (Table VIII).

Finch and others (1951) used the Evans' blue method in a group of twenty patients, seventeen of whom had rheumatoid arthritis, and reported a mean decrease in the blood volume, compared with the normal figures of Gibson and Evans (1937), with height as the standard of reference. They do not give enough data for us to analyse whether factors such as age, sex and body-weight could have influenced this comparison.

Chaplin and others (1953) and Verel (1954) stressed the constancy of the ratio of the "whole body" haematocrit to the peripheral haematocrit in the absence of splenic enlargement. In our patients

* A misprint in Gibson and Evans' paper gives 38.9 as the average age of his women subjects. This should apparently have been $31 \cdot 5$ years.

TABLE VIII

COMPARISON OF JEFFREY'S RESULTS WITH THOSE OF GIBSON AND EVANS

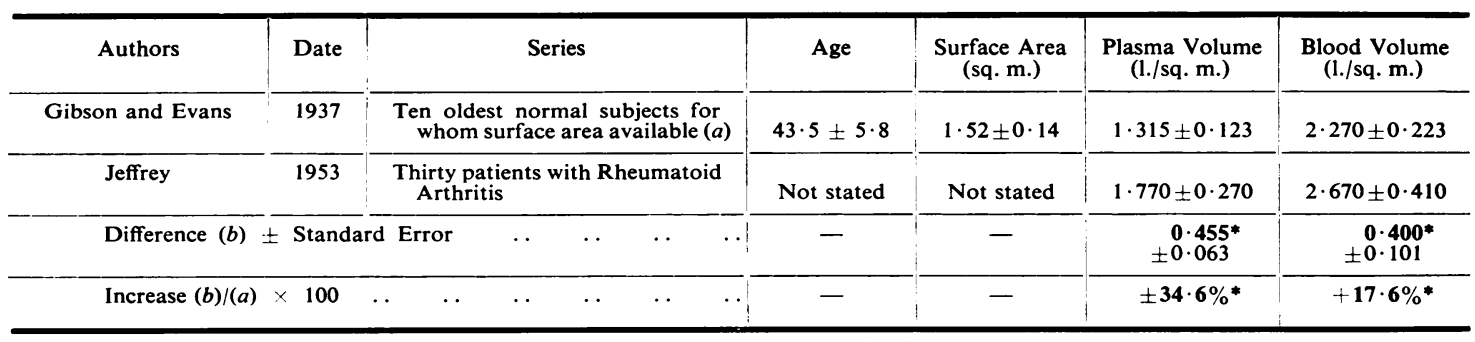

* Differences in bold type are significant. 
this ratio (Table V) was $0.912 \pm 0.048$, and not significantly different from that found for the control subjects $(0.932 \pm 0.037)$. These figures are not significantly different from those of others* (Chaplin and others, 1953; Verel, 1954; Barnes and others, 1948; Berson and Yalow, 1952; Brady and others, 1953; Gibson and others, 1946; Gray and Frank, 1953; Meneely and others, 1947; Nachman and others, 1950; Reeve and Veall, 1949), who measured red cell mass and plasma volume simultaneously by various techniques.

Our results bear upon the problem of the anaemia of rheumatoid arthritis. Anaemia is a common feature of this disease, being present in 33 per cent. of women with rheumatoid arthritis compared with less than 10 per cent. of a matched series of normal women, and in 49 per cent. of men with rheumatoid arthritis compared with $7 \cdot 4$ per cent. of normal men (Lewis-Faning, 1950). The degree of anaemia that is present roughly parallels the activity of the disease process, both in groups of patients (Jeffrey, 1953) and in our experience of the long-term course of the individual patient (Giansiracusa and others, 1951). Evidence of four different kinds points away from an abnormality of the red cells and therefore toward the plasma as being the cause of this apparent anaemia.

When the other manifestations of rheumatoid disease are suppressed by cortisone acetate or adrenocorticotrophic hormone, the anaemia improves, as first noted by Hench (1952). Since this is in contrast to the effect of ACTH in normal subjects (Mason and others, 1948), we regard changes in the anaemia of arthritis provoked by changes in cortisone therapy as comparable with those occurring in spontaneous remissions and relapses. In our patients cortisone withdrawal was followed by immediate expansion of plasma volume and by anaemia without reduction in red cell mass. Conversely, patients who were treated with cortisone by Copeman and others (1952), showed an improvement in their anaemia; this was almost entirely accounted for by decrease of plasma volume in the one case in which the detailed observations are given. On the other hand, Finch and others (1951), using the Evans' blue-haematocrit method, found an absolute increase in blood volume and red cell mass in those of their patients whose anaemia improved under cortisone therapy.

Secondly, the anaemia of rheumatoid arthritis is refractory to specific haematinic therapy. Sinclair and Duthie (1950) reported success with intravenous iron, but in their study general remission of the

\footnotetext{
* Haematocrits corrected where necessary, $\times 0.97$ for trapped plasma.
}

disease could not be excluded as the cause of the $\frac{\mathbb{2}}{3}$ improvement noted in haemoglobin concentrations 0 and their results have not been confirmed by another team (Kuhns and others, 1950).

Thirdly, although comparatively little work has $\stackrel{5}{?}$ been done on some aspects of this subject, it can be? said that so far no abnormality of red cell or of $\frac{\overline{\bar{\omega}}}{\bar{D}}$ haemoglobin production or destruction (with one $\frac{\hat{\sigma}}{\widetilde{D}}$ exception), or of iron absorption or metabolism has $\mathbb{Q}$ been found to cause or correlate with the anaemia of rheumatoid arthritis. The exception to this statement is red cell survival time which Friereich:(1954), using the technique of Ashby (1919), found $\vec{\omega}$ to be decreased in six out of twelve patients with rheumatoid arthritis.

Fourthly, our blood volume comparisons accord with the concept of an increased plasma volume in rheumatoid arthritis.

Nevertheless, it cannot be too strongly emphasizedo that caution is needed in applying results derived ${ }_{-}^{\text {. }}$ from a selected group of ten women with arthritis 3 to all with this disease, and that the conclusion that the blood volume in rheumatoid arthritis is expanded 5 depends on what normals are used for comparison $\vec{\varphi}$ and on the standards of reference on which this $\mathrm{G}$ comparison is based. The possibility of significant changes in red cell mass in rheumatoid arthritis, though not found, has not been excluded.

\section{Summary}

In 23 patients with chronic, active, rheumatoid $\overrightarrow{\vec{Q}}$ arthritis or spondylitis, the plasma retention of congo red at the end of one hour was $55 \pm 10 \cdot 2$ 年 per cent. of the amount injected, as compared with a one-hour plasma retention of Evans' blue of $86 \cdot 1 \pm 1 \cdot 2$ per cent. There was no correlation for individual patients between the two dye retentions.

Plasma volume measurements in the same patients showed that the congo red method frequently gave high and unreliable results in this disease. Entryo of the dyes into inflamed joints did not explain these observations.

Evans' blue disappears from the circulation slightly faster in rheumatoid arthritis than in normap subjects. The difference, though significant, does not affect the reliability of this dye in measuring blood volume in this disease. Plasma volume measurements in one patient with amyloidosis were unreliable with both dyes.

Cortisone acetate treatment was abruptly stoppe in one patient with rheumatoid spondylitis who had been maintained in clinical remission with the aid of this hormone. Both arthritis and anaemi promptly recurred, and serial measurements sug 
gested that the anaemia was the result of expansion of the plasma volume.

Plasma volume by the Evans' blue method and red cell mass by the radio-active sodium chromate method were measured simultaneously in ten women with typical moderately severe active peripheral rheumatoid arthritis and in ten normal women, matched as closely as possible for age. The arthritis patients were more anaemic than the normals; this difference was associated with a significant increase of plasma volume of 20.4 per cent., and a significant increase of blood volume of 9.6 per cent. A $7 \cdot 1$ per cent. fall in red cell mass failed to reach significance levels. It is not likely that expansion of the plasma volume is the only cause for the anaemia of rheumatoid arthritis in all patients with this disease.

The authors wish to thank Dr. W. E. Reynolds and Miss Rita J. Nickerson of the Department of Preventive Medicine, Harvard Medical School, for statistical assistance, Dr. John Raker and Miss Rosemary Sims for help with the sodium chromate $-{ }^{51} \mathrm{Cr}$ studies, and $\mathrm{Dr}$. Lewis Dahl and Dr. Vincent Dole for the data summarized in Table III.

\section{REFERENCES}

Ashby, W. (1919). J. exp. Med., 29, 267.

Barnes, D. W. H., Loutit, J. F., and Reeve, E. B. (1948). Clin. Sci., $7,135$.

Bauer, W., and Bennett, G. A. Unpublished observations.

, Ropes, M. W., and Waine, H. (1940). Physiol. Rev., 20, 272. Bennhold, H. (1923). Dtsch. Arch. klin. Med., 142, 32.

Berlin, N. I., Hyde, G. M., Parsons, R. J., Lawrence, J. H., and Port, S. (1951). Proc. Soc. exp. Biol.' (N.Y.), 76, 831.

Berson, S. A., and Yalow, R. S. (1952). J. clin. Invest., 31, 572.

Boothby, W. M., and Sandiford, I. (1929). Amer. J. Physiol., $90,290$.

Brady, L. W., Cooper, D. Y., Colodzin, M., McClenathan, J. E., King, E. R., and Williams, R. (1953). Surg. Gynaec., Obstet., 97, 25 .

Chaplin, H., Mollison, P. L., and Vetter, H. (1953). J. clin. Invest., 32, 1309.

Copeman, W. S. C., Savage, O., Bishop, P. M. F., Dodds, E. C., Kellie, A. E., Stewart, J. W., Glyn, J. H. H., Henly, A. A., and Tweed, J. M. (1952). Brit. med. J., 1, 397.

Cruickshank, E. W. H., and Whitfield, I. C. (1944). J. Physiol. (Lond.), 103, 198.

Deitrick, J. E., Whedon, G. D., and Shorr, E. (1948). Amer. J. Med., 4, 3 .

Drinker, C. K., and Field, M. E. (1933). "'Lymphatics, Lymph and Tissue Fluid". Williams and Wilkins, Baltimore.

Dubois, E. F. (1927). "Basal Metabolism in Health and Disease", 2nd ed., p. 151. Lea and Febiger, Philadelphia.

Finch, S. C., Crockett, C. L., Ross, J. F., and Bayles, T. B. (1951). Blood, 6, 1034.

Friedlander, M., Laskey, N., and Silbert, S. (1935). Endocrinology, 19,461

Friedman, M. M., and Auerbach, O. (1935). J. Lab. clin. Med., 21, 93 .

Friereich, E. J. (1954). Lancet, 2, 122.

Garry, M. W. (1952). Amer. J. med. Sci., 223, 642.

Gibson, J. G., and Evans, W. A. (1937). J. clin. Invest., 16, 317. G, and Evelyn, K. A. (1938). Ibid., 17, 153. Peacock, W. C., Seligman, A. M., and Sack, T. (1946). Ibid., 25, 838.

Giansiracusa, J. E., Ropes, M. W., Kulka, J. P., and Bauer, W. (1951). Amer. J. Med., 10, 419.

Gornall, A. G., Bardawill, C. J., and David, M. M. (1949). J. biol. Chem., 177, 751.

Gray, S. J., and Frank, H. (1953). J. clin. Invest., 32, 1000

Gregersen, M. I., and Schiro, H. (1938). Amer. J. Physiol., 121, 284. Harmon, P. H., and Kernwein, G. (1942). Arch. intern. Med., 70, 416.

Hass, G., and Schulz, R. Z. (1940). Arch. Path. (Chicago), 30, 240.
Hench, P. S. (1952). In American Rheumatism Association: "Rheumatic Diseases". Saunders, Philadelphia.

Jeffrey, M. R. (1953). Blood, 8, 502 .

Krogh, A. (1929). "The Anatomy and Physiology of Capillaries", 2nd ed. Yale University Press, New Haven.

Kuhns, W. J., Gubler, C. J., Cartwright, G. E., and Wintrobe, M. M. (1950). J. clin. Invest., 29, 1505.

Lewis-Faning, E. (1950). Annals of the Rheumatic Diseases, 9. Suppl.

Lipstein, S. (1938). Amer. J. med. Sci., 195, 205.

Mason, H. L., Power, M. H., Rynearson, E. H., Ciaramelli, L. C., Li, C. H., and Evans, H. M. (1948). J. clin. Endocrinol., 8, 1.

Massachusetts General Hospital (Case No. 27331) (1941). New Engl. J. Med., 225, 269.

- (Case No. 34531) (1948). Ibid., 239, 1047.

Meneely, G. R., Wells, E. B., and Hahn, P. F. (1947). Amer. J. Physiol., 148, 531.

Nachman, H. M., James, G. W., Moore, J. W., and Evans, E. I. (1950). J. clin. Invest., 29, 258.

Pearlman, A. W. (1940), Quart. Bull. Seaview Hosp., 6, 92.

Reeve, E. B., and Veall, N. (1949). J. Physiol. (Lond.), 108, 12.

Robinson, G. L. (1943). Annals of the Rheumatic Diseases, 3, 207.

Rourke, M. D., and Ernstene, A. C. (1930). J. clin. Invest., 8, 545.

Rowntree, L. G., Brown, G. E., and Roth, G. M. (1929). "The Volume of the Blood and Plasma in Health and Disease", p. 44. Saunders, Philadelphia.

Sinclair, R. J. G., and Duthie, J. J. R. (1950). Brit. med. J., 2, 1257.

Smith, H. P. (1925). Bull. Johns Hopk. Hosp., 36, 325.

Sparks, M. I., and Haden, R. L. (1932). Amer. J. med. Sci., 184, 753.

Steinbrosker, O., Traeger, C. H., and Batterman, R. C. (1949). J. Amer. med. Ass., 140, 659.

Stemmerman, M., and Auerbach, O. (1944). Amer. J. med. Sci., $208,305$.

Sterling, K., and Gray, S. J. (1950). J. clin. Invest., 29, 1614.

Sterling, K., and Gray, S. J. (1950). J. clin. Invest., 29, 1614.

Unger, P.' N., Zuckerbrod, M., Beck, G. J., Steele, J. M. (1948). J. clin. Invest., 27, 111.

Thompson, W. O., Thompson, P. K., and Dailey, M. E. (1928). Ibid., 5, 573 .

Verel, D. (1954). Clin. Sci., 13, 51.

Waterfield, R. L. (1931). J. Physiol. (Lond.), 72, 110.

Arthrite rhumatismale: l'étude de la rétention des colorants et la comparaison des colorants et des globules rouges radioactivement marquées dans les procédés de mesure du volume sanguin

RÉSUMÉ

Chez 23 malades atteints d'arthrite rhumatismale chronique et active ou de spondylite, la rétention par le plasma du rouge Congo au bout d'une heure fut $55 \pm 10,2$ pour cent de la quantité injectée et celle du bleu d'Evans $86,1 \pm 1,2$ pour cent. Il n'y eut pas de corrélation pour des malades individuels entre les pourcentages de rétention pour chaque colorant.

La mesure répétée du volume du plasma chez de mêmes malades montra que le rouge Congo donne souvent des chiffres élevés et peu fidèles dans cette maladie. La pénétration des colorants dans les articulations enflammées n'explique pas ces observations.

Le bleu d'Evans dispara $t$ de la circulation un peu plus vite chez les rhumatisants que chez les hommes normaux. Cette différence, bien que significative, ne concerne pas l'exactitude de ce colorant comme indicateur du volume sanguin dans cette maladie. Le mesure du volume plasmatique chez un malade atteint de dégénérescence amyloïde donna des résultats imprécis avec les deux colorants.

On arrêta brusquement l'administration d'acétate de cortisone à un malade atteint de spondylite rhumatismale, jusqu'à alors en état de rémission grâce à cet hormone. L'arthrite et l'anémie retournèrent rapidement, et une série de déterminations indiqua que l'anémie résulta de l'expansion du volume plasmatique.

On détermina simultanément le volume plasmatique à l'aide du bleu d'Evans et la masse des globules rouges à l'aide du chromate de soude radioactif chez 10 femmes atteintes d'arthrite rhumatismale périphérique active et de gravité modérée et chez 10 femmes normales d'âges 
correspondants. Les arthritiques furent plus anémiques que les normales; cette différence fut associée à une augmentation appréciable du volume plasmatique de 20,4 pour cent et à une augmentation appréciable du volume sanguin de 9,6 pour cent. Une diminution de la masse des globules rouges de 7,1 pour cent manqua la limite de la signification statistique. Il est peu probable que l'expansion du volume plasmatique soit la seule cause de l'anémie rhumatismale chez tous les rhumatisants.

Artritis reumatoide: estudio de la retención de los colorantes y comparación de los colorantes con los eritrocitos marcados radioactivemente en los procedimientos de medida del volumen sanguíneo

\section{Sumario}

En 23 enfermos con artritis reumatoide crónica activa o con espondilitis, la retención en el plasma del rojo Congo al cabo de una hora fué el $55 \pm 10,2$ por ciento de la cantidad inyectada y la de azúl de Evans el 86,1 $\pm 1,2$ por ciento. No hubo correlación para enfermos individuales entre los porcentages de retención de cada colorante.

Midiendo repetidamente el volumen plasmático en los mismos enfermos se pudo ver que el rojo Congo produce a menudo cifras altas e inciertas. La penetración de los colorantes en las articulaciones inflamadas no explica estas observaciones.

El azúl de Evans desaparece de la circulación algọ. más pronto en los reumáticos que en los sujetos normales. Esta diferencia, aunque significativa, no atañe la precisión de este colorante como índice de volumen sanguíneo e $\vec{B}$ esta enfermedad. La medida del volumen plasmático en un enfermo con amiloidosis dió resultados de poca. precisión con ambos colorantes.

Se interrumpió de repente la administración de acetatio de cortisona a un enfermo con espondilitis reumatoide sostenido hasta entonces en remisión con esta hormonan $\mathrm{La}$ artritis y la anemia volvieron en seguida y una serie de medidas indicó que la expansión del volumen plasmático fué la causa de la anemia.

Se determinó simultáneamente el volumen plasmátiç্ঠু con azúl de Evans y la masa eritrocitaria con cromato de sodio radioactivo en 10 mujeres con artritis reumatoids periférica activa de gravedad moderada y en 10 mujeres normales de edades correspondientes. Las artríticas fueron más anémicas que las mujeres normales; está diferencia fué asociada a una aumentación apreciable de्e volumen sanguíneo de un 9,6 por ciento. La disminu ción de la masa eritrocitaria de un 7,1 por ciento ne alcanzó el límite estadisticamente significativo. Es pocơ probable que la expansión del volumen plasmático sea única causa de la anemia reumática en todos los enfermoš 